\title{
Effects of Lactobacillus plantarum BCC65951 inoculation in Napier Pakchong 1 silage on in vitro rumen degradability and growth performance of Brahman cattle
}

\section{Saowaluck Yammuen-art}

Chiang Mai University Faculty of Agriculture

\section{Soparak Khemarach}

Chiang Mai University Faculty of Agriculture

\section{Kattareeya Taja}

Chiang Mai University Faculty of Agriculture

\section{Vethachai Plengvidhya}

National center for Genetic Engineering and Biotechnology

Ittiphon Phaopaisal

bureau of animal nutrition development, department of livestock development

\section{Kittima Kongtong}

National center for Genetic Engineering and Biotechnology

Siwat Sangsritavong ( $\nabla$ siwat@biotec.or.th )

National Center for Genetic Engineering and Biotechnology (BIOTEC) https://orcid.org/0000-00032329-7532

\section{Research}

Keywords: Lactobacillus plantarum BCC65951, Napier Pakchong 1, rumen degradability, growth performance, Brahman cattle

Posted Date: March 23rd, 2020

DOI: https://doi.org/10.21203/rs.3.rs-18658/v1

License: (c) (i) This work is licensed under a Creative Commons Attribution 4.0 International License. Read Full License 


\section{Abstract}

Background: Napier grass Pakchong 1 is used as a fodder crop in Southeast Asia. Unfortunately, its fermentation for silage production is challenging owing to the low dry mass content and epiphytic lactic acid bacteria. Here, Lactobacillus plantarum BCC65951 (LAB) inoculation was tested for impact on silage fermentation and use. Silage was prepared with or without inoculation of LAB and stored for 180 days prior to analysis.

Results: Gas production at 4-24 h was significantly higher in LAB group ( $P=0.001)$. Therefore, the result implied the faster ruminal degradation of $L A B$, especially during the first $24 \mathrm{~h}$. LAB-inoculated silage exhibited greater levels of lactic acid and in vitro rumen degradability compared to control silage, and significantly lower $\mathrm{pH}$ and acetic acid content. To investigate the effect of LAB inoculation on animal performance, ten Brahman bulls were fed on control or LAB-inoculated silage in a crossover experimental design. Animals fed with LAB-inoculated silage had significantly higher voluntary roughage intake and greater average daily body weight gain than those fed with control silage.

Conclusions: Results from this study revealed the beneficial effect of Napier Pakchong 1 ensiled with $L$. plantarum BCC65951 inoculation, both on the fermentative quality of the silage and also the performance of animals fed with the inoculated silage.

\section{Introduction}

Napier Pakchong 1 grass, a hybrid between Pennisetum purpureum x P. glaucum, developed at the Nakhon-Ratchasima Animal Nutrition Research and Development Center, Thailand, is used as a fodder crop [1]. It is notable for its high yield (about $6200 \mathrm{~kg}$. fresh grass/hectare per cutting at 45-60 days of maturity) [1]. Therefore, it is grown throughout Thailand and neighboring countries in Southeast Asia for both ruminant feed and also biomass for energy production (Figure 1).

In the view of animal feed, the forage is produced in excess of animal consumption during the rainy season, but the yield of fresh grass is inadequate in dry season since most of the grass is grown in areas without irrigation. Preserving the surplus forage in form of silage during the rainy season is the most appropriate way to meet the roughage requirement all year round. However, making Napier grass silage is challenging because of the grass has low dry matter contents (approximately $16-20 \%$ ). Similar to other tropical grass, Napier grass is also low in epiphytic lactic acid bacteria which are essential for ensiling to produce good quality silage $[2,3]$. Napier grass silage always has a low and inconsistent fermentative quality and more importantly the quality of silage often decline rapidly led to the short storage lifetime i.e. less than 90 days. The low density of epiphytic lactic acid bacteria in tropical forage compared with other microorganisms means that production of lactic acid is insufficient to maintain the low pH necessary for fermentation during the ensiling process [3].

Previous studies showed that inoculation of lactic acid bacterial (LAB) improved fermentative quality of silage when compared with grass silage fermented without inoculation(Driehuis, Oude Elferink, \& Van 
Wikselaar, 2001). Furthermore dry matter loss and densities of undesirable bacteria in the inoculated silage were also lower [4]. However, commercial starter cultures are isolated from epiphytic bacteria of fodder crop grown in the temperate zone which are poorly adapted to the tropical climate with higher temperature and humidity [5]. For this reason, the use of starter culture isolated from forage grown in the tropics could be an appropriate approach to increase fermentative quality, rumen degradability, extend storage time and also improve growth performance of cattle.

Lactobacillus plantarum (L. plantarum) is a lactic acid bacterium that is commonly found in forage. It is a facultative heterofermentative bacterium that ferments sugars to produce lactic acid, ethanol or acetic acid, and carbon dioxide. Moreover, L. plantarum fermentation is associated with reduced deamination which preserves protein integrity [6]. The consistent increases of microbial biomass shown by previous in vitro study may explain its positive effects on milk production and animal growth performance [6].

Lactobacillus plantarum BCC65951 was isolated from sugarcane silage; therefore, it could be well-suited as a silage starter for the fermentation of the silage under typical conditions of tropical countries. The objectives of this study were to determine fermentative quality, rumen degradability of Napier Pakchong 1 ensiled with or without an inoculation of Lactobacillus plantarum BCC 65951. In addition, growth performance of Brahman cattle fed Napier Pakchong 1 ensiled with or without an inoculation and stored for 180 days was also investigated.

\section{Material And Methods}

\section{Strain and cultivation condition}

L. plantarum BCC 65951 were grown for $16-18 \mathrm{~h}$ at $37^{\circ} \mathrm{C}$ in MRS (Difco, Fisher Scientific, Pittsburgh, PA, USA) broth harvested by centrifugation (Beckman Coulter Avanti J-E, Beckman Coulter Life Sciences, Indianapolis, IN, USA) at $10,000 \times$ G for 10 minutes, washed and resuspended with $0.85 \%$ saline solution. The cultures were diluted to supply a starting concentration of approximately $10^{7} \mathrm{cfu} / \mathrm{g}$ fresh forage in the silage fermentations.

\section{Ensiling process}

Napier Pakchong 1 grass was harvested at 60 days of maturity and ensiled into two treatments: no inoculants (control) and inoculated with L. plantarum BCC65951 at $10^{7} \mathrm{cfu} / \mathrm{g}$ fresh weight. Silages were prepared using a small scale system, approximately $20 \mathrm{~kg}$ portions of forage material chopped into 1-3 $\mathrm{cm}$. length, which was packed tightly in layered plastic bags and vacuum seal. The plastic bags were stored at ambient temperature for 180 days. Thereafter approximately $1 \mathrm{~kg}$ of each replicate was collected as the representative of the experimental silage, the samples were kept at minus $20^{\circ} \mathrm{C}$ before subjected to chemical and rumen degradability analyses.

\section{Analysis of fermentation quality}


The silage samples were collected at different positions including at the top, in the middle and in the bottom of the stack and finally mixed together. For chemical analysis, $12.5 \mathrm{~g}$ of the shredded Napier grass samples were homogenized in a $0.02 \mathrm{ml} \mathrm{N} \mathrm{H}_{2} \mathrm{SO}_{4}$ in a stomacher (Seward,West Sussex, UK) for 4 $\mathrm{min}$ at $200 \mathrm{rpm}$. The extract was centrifuged $\left(10,000 \mathrm{rpm}, 4^{0} \mathrm{C}, 10 \mathrm{~min}\right)$ and filtered through $0.45 \mu \mathrm{m}$ membranes (Minisart RC4) prior to be analyzed for fermentation quality [7]. The extract was measured for $\mathrm{pH}$ value immediately with a $\mathrm{pH}$ meter (Sartorius PB-20, Goettingen, Germany). The volatile fatty acids (VFAs) were analyzed by gas chromatography (GC) [7] . The lactic acid contents were measured by HPLCUV using a Bio-Rad Aminex HPX-87H column (Bio-Rad Lab., Hercules, CA, USA) with a $0.6 \mathrm{ml} / \mathrm{min}$ flow rate of $0.02 \mathrm{~N} \mathrm{H}_{2} \mathrm{SO}_{4}$ at $60^{\circ} \mathrm{C}$ [8]

\section{Chemical Composition Analysis}

The fresh samples were dried at $60^{\circ} \mathrm{C}$ for $48 \mathrm{~h}$. After that, the sample was ground through a $1 \mathrm{~mm}$ of sieve size with a Wiley Mill. Dry matter (DM; Method 934.01, [9]), crude protein (CP; Method 968.06, [9]), ether extract (EE; Method 920.39, [9]) and crude fiber (CF; Method 962.06, [9]) were analyzed. Neutral detergent fiber (NDF), acid detergent fiber (ADF) and acid detergent lignin (ADL) were analyzed using Detergent methods [10].

\section{Determination of rumen degradability by in vitro gas-production technique}

Rumen fluid was collected from four fistulated Thai native bulls. About $230 \mathrm{mg}$ of feed was weighed into $100 \mathrm{ml}$ calibrated glass syringes. Rumen fluid was added to the buffered mineral solution $\left(9.8 \mathrm{~g} \mathrm{NaHCO}_{3}\right.$ $+2.77 \mathrm{~g} \mathrm{Na}_{2} \mathrm{HPO}_{4}+0.57 \mathrm{~g} \mathrm{KCl}+0.47 \mathrm{~g} \mathrm{NaCl}+0.12 \mathrm{~g} \mathrm{MgSO}_{4} \cdot 7 \mathrm{H}_{2} \mathrm{O}+0.16 \mathrm{~g} \mathrm{CaCl}_{2} \cdot 2 \mathrm{H}_{2} 0$ ), and maintained

in a water bath at $39^{\circ} \mathrm{C}$ under continuous flushing with $\mathrm{CO}_{2}$. About $30 \mathrm{ml}$ of buffered rumen fluid was dispensed into syringes containing the samples and all syringes were incubated in a water bath maintained at $39^{\circ} \mathrm{C}$. Gas production was determined at $4,8,12,24,48,72$ and $96 \mathrm{~h}$ of incubation.

Net gas productions ( $\mathrm{ml} / 200 \mathrm{mg}, \mathrm{DM})$ after $24 \mathrm{~h}$ incubation was calculated using the equations as follows [11]:

$(\mathrm{ml} / 200 \mathrm{mg} \mathrm{DM})=$

Where

$G P_{t}=$ Net gas production $(\mathrm{ml} / 200 \mathrm{mg}, \mathrm{DM})$ after $24 \mathrm{~h}$ incubation

$\mathrm{V}_{\mathrm{t}}=$ Gas volume at time $t$

$\mathrm{V}_{\mathrm{t}}=$ Gas volume at $t=0$

$G P_{0}=$ Blank value at time $t$

W = Weight in mg DM of sample in each syringe 
$\mathrm{FH}=$ Correction factor of hay

FC $=$ Correction factor of concentrate

The incubation residue was distilled by neutral detergent solution to remove the microbial biomass from undegraded substrate [12]. The microbial biomass yield (MBY) was calculated after $24 \mathrm{~h}$ incubation according to the following formula:

MBY = truly digested sample - apparently digested sample

truly digested sample

\section{Measurement of growth performance}

Ten Brahman bull (10.3 \pm 0.8 month) with average $205 \pm 12.8 \mathrm{~kg}$ of body weight were housed in individual pens. Vaccination against epidemic diseases and anthelmintic were applied for parasites elimination 10 days before the experiment started and all the experimental animals were allowed to have the adaptation period with the experimental diet for 15 days. The experiment was conducted with a cross-over design. The cattle were fed $1.81 \mathrm{~kg}$. DM/head/d of concentrate and ad libitum silage. Clean drinking water was available at all time. To assure that the animals received feed ad libitum, silage was offered until at least $5 \%$ refusal was obtained. Feed offered and refused were weighted every day to calculate voluntary feed intake. To weight the animal, all feed was taken away from feed bunk at 8.00 PM the day before, and all animals were weighted at $8.00 \mathrm{AM}$ on the following day and fresh feed was provided. This weighting procedure was repeated for 2 consecutive days at the beginning of the experiment after adaptation period and also at the end of each particular period. Average live weights of each individual animal were recorded for statistical analysis.

\section{Statistical analysis}

The fermentation quality of silage, chemical composition and in vitro gas production technique was tested for the equality of variance then statistically analyzed by t-test while, growth performance was statistically analyzed according to the cross-over design using SPSS program. Differences among means were tested using the adjusted Duncan's test, the significance declared at $P<0.05$ [13].

\section{Results}

\section{Fermentative quality of silage}

The organic acid production and $\mathrm{pH}$ at the end of the ensiling study period are summarized in table 1. Lactic acid was the predominant organic acid detected in both control and starter culture inoculated fermentation followed by acetic acid whereas butyric acid was presented in low amount. The results obtained from the statistical analysis showed that ensilaging with L. plantarum starter culture significantly influenced $\mathrm{pH}$, lactic and acetic production $(P<0.05)$ but did not affect the productions of 
butyric acid. At the end of the studied period, the $\mathrm{pH}$ value of silage fermented with $L$. plantarum inoculants was significantly lower than that of control fermentation. Although the total acids production of the control and LAB group was not significantly different, but silage fermented with added starter culture had significantly higher concentrations of lactic acid as well as significantly lower acetic acid concentration when compared with control fermentation (Table 1). Addition of L. plantarum starter culture contributed to significantly different in the organic acid ratio of silage. Silage fermented with added starter culture has higher lactic acid and lower acetic ratio than that of the control fermented silage.

Table 1 Organic acids profile of silage with or without LAB inoculation

\begin{tabular}{|c|c|c|c|c|c|c|c|c|}
\hline \multirow[t]{2}{*}{ Item } & \multirow[t]{2}{*}{$\mathrm{pH}$} & \multicolumn{4}{|c|}{ gram/100grams Dry Weight } & \multicolumn{3}{|c|}{ Ratio of organic acid (\%) } \\
\hline & & Lactic & Acetic & Butyric & Total acid ${ }^{\mathrm{a}}$ & Lactic & Acetic & Butyric \\
\hline$C$ & $4.36^{a}$ & $5.94^{b}$ & $3.06^{\mathrm{a}}$ & 0.85 & 11.06 & $54.04^{b}$ & $27.55^{a}$ & 7.64 \\
\hline $\mathrm{LAB}$ & $3.92^{\mathrm{b}}$ & $8.37^{\mathrm{a}}$ & $1.14^{\mathrm{b}}$ & 0.47 & 10.85 & $77.16^{\mathrm{a}}$ & $10.88^{b}$ & 4.06 \\
\hline SEM & 0.08 & 0.49 & 0.44 & 0.22 & 0.82 & 3.27 & 3.50 & 1.82 \\
\hline$P$-value & 0.002 & 0.002 & 0.005 & 0.135 & 0.805 & $<0.001$ & 0.003 & 0.097 \\
\hline
\end{tabular}

\section{Chemical composition of silage}

Dry matter and organic matter percentage of silage in control group were higher than that of in LAB $(P<0.05)$ (Table 2). Crude protein, ether extract, water soluble carbohydrate, neutral detergent fiber, acid detergent fiber, acid detergent lignin, cellulose and hemi-cellulose of Napier silage in both control and LAB groups did not differ significantly.

Table 2 Nutrient compositions of silage fermented with or without L. plantarum BCC65951 inoculation 


\begin{tabular}{lllll} 
Nutrient composition (\%) & \multicolumn{2}{l}{ Treatment } & SEM & P-value \\
\cline { 2 - 4 } & Control & $\begin{array}{l}\text { L. plantarum } \\
\text { BCC } 65951\end{array}$ & \\
\cline { 2 - 4 } Dry matter & $21.31^{\mathrm{a}}$ & $20.10^{\mathrm{b}}$ & 0.238 & 0.005 \\
\hline Organic matter & $89.80^{\mathrm{a}}$ & $88.50^{\mathrm{b}}$ & 0.384 & 0.022 \\
\hline Crud fiber & 33.31 & 33.74 & 0.226 & 0.457 \\
\hline Crud protein & 6.71 & 6.80 & 0.130 & 0.789 \\
\hline Ether extract & 3.16 & 3.75 & 0.225 & 0.244 \\
\hline Water soluble carbohydrate & 17.17 & 14.10 & 1.040 & 0.147 \\
\hline Ash free neutral detergent fiber & 62.77 & 63.85 & 0.395 & 0.208 \\
\hline Ash free acid detergent fiber & 46.51 & 47.40 & 0.678 & 0.621 \\
\hline Acid detergent lignin & 7.99 & 7.61 & 0.225 & 0.513 \\
\hline Cellulose & 38.53 & 39.80 & 0.575 & 0.363 \\
\hline Hemi-cellulose & 16.26 & 16.47 & 0.389 & 0.852
\end{tabular}

a, b Means within a row with different superscripts are significantly different $(P<0.05)$

\section{Rumen degradability}

Table 3 showed that gas production during 4-24 h incubation was significantly higher in LAB than that of the control group. Thus, the result revealed that grass silage ensiled with L. plantarum BCC65951 has digested faster by bacteria in the rumen, especially during the first $24 \mathrm{~h}$ of the degradation.

Table 3 In vitro rumen degradability and microbial biomass yield of silage with or without $L$. plantarum BCC 65951 inoculations 


\begin{tabular}{|c|c|}
\hline \multirow[t]{2}{*}{ Item } & Treatment \\
\hline & Control \\
\hline
\end{tabular}

\begin{tabular}{llll}
\multicolumn{1}{l}{ Gas production (milliliter) } & & & \\
\cline { 1 - 4 } at $4 \mathrm{~h}$ of incubation & $7.20^{\mathrm{b}} \pm 0.75$ & $7.99^{\mathrm{a}} \pm 0.48$ & 0.033 \\
\hline at $8 \mathrm{~h}$ of incubation & $14.91^{\mathrm{b}} \pm 1.37$ & $16.75^{\mathrm{a}} \pm 1.03$ & 0.013 \\
\hline at $12 \mathrm{~h}$ of incubation & $16.45^{\mathrm{b}} \pm 2.10$ & $18.67^{\mathrm{a}} \pm 1.08$ & 0.018 \\
\hline at $24 \mathrm{~h}$ of incubation & $22.42^{\mathrm{b}} \pm 1.90$ & $26.27^{\mathrm{a}} \pm 1.83$ & 0.001 \\
\hline at $48 \mathrm{~h}$ of incubation & $41.51 \pm 2.77$ & $43.54 \pm 6.75$ & 0.454 \\
\hline at $72 \mathrm{~h}$ of incubation & $53.01 \pm 3.28$ & $53.89 \pm 8.04$ & 0.775 \\
\hline at $96 \mathrm{~h}$ of incubation & $58.15 \pm 4.64$ & $58.23 \pm 8.86$ & 0.980 \\
\hline Microbial biomass yield & & & 0.936 \\
\hline (gram) & $0.0788 \pm 0.09$ & $0.0789 \pm 0.08$ & 0.181
\end{tabular}

a, b Means within a row with different superscripts are significantly different $(P<0.05)$.

\section{Animal performance}

Feed ingredients and chemical composition of the concentrate that offered to the animals in this experiment was presented in Table 4, whereas table 2 showed chemical composition of experimental silage. Each individual animal received $1.81 \mathrm{~kg}$.DM of concentrate feed per day and ad libitum silage. Voluntary feed intake of inoculated silage was significantly greater than the intake in control group (Table 5). However, the chemical composition of concentrate and Napier Pakchong 1 silage with or without inoculation was not significantly different. The average daily gain of the bulls receiving inoculated silage was significantly greater when compared with the animal received control fermented silage (Table 5).

Table 4 Feed ingredients and Chemical composition of the concentrate 


\begin{tabular}{llll} 
Ingredient & $(\%)$ & Chemical composition & $(\%)$ \\
\hline Rice bran & 50.8 & Dry matter & 90.5 \\
\hline Cassava chip & 10.0 & Crud protein & 18.0 \\
\hline Soybean meal & 35.2 & Total Digestible Nutrients & 77.9 \\
\hline Dicalcium phosphate & 2.0 & Ether extract & 2.4 \\
\hline Vitamin and mineral premix & 2.0 & Ash free acid detergent fiber & 7.9 \\
\hline Ash free neutral detergent fiber & 13.7 & &
\end{tabular}

Table 5 Feed intake and growth performance of Brahman cattle fed on Napier silage without or with inoculation

\begin{tabular}{|c|c|c|}
\hline Item & Control & L. plantarum BCC 65951 \\
\hline Number of the bulls $(\mathrm{N})$ & 10 & 10 \\
\hline \multicolumn{3}{|l|}{ Feed intake (DMI) kg/head/day } \\
\hline Concentrate & 1.81 & 1.81 \\
\hline Roughage & $3.12 \pm 0.1^{b}$ & $3.28 \pm 0.1^{\mathrm{a}}(+5.21 \%)$ \\
\hline \multicolumn{3}{|l|}{ Growth performance } \\
\hline Initial weight (kg士SEM) & $204.8 \pm 16.8$ & $205.2 \pm 4.6$ \\
\hline Average Daily Gain (gram \pm SEM & $557.1 \pm 88.4^{b}$ & $792.7 \pm 108.3^{a}(+42.29 \%)$ \\
\hline
\end{tabular}

a, b Means within a row with different superscripts are significantly different $(P<0.05)$

\section{Discussion}

\section{Fermentative quality of silage}

The $\mathrm{pH}$, organic acids concentration and proportion of the organic acids namely lactic, acetic, and butyric acid with total acid founded in silage fermentation can be used as an indicator of silage quality [14]. Several studies have shown the benefit of adding LAB inoculants in silage fermentation to ensure rapid accumulation of organic acids during the ensiling period, which will be leading to the lower pH values [1518]. In this study, inoculation of Napier silage with L. plantarum improved fermentation as reflected in reductions in $\mathrm{pH}$ value and acetic acid, concentrations, together with an increase of lactic acid concentrations when compared with the control fermented silage. Furthermore, fermentation with added L. plantarum starter culture contributes to significantly higher lactic and lower acetic ratio. Silage treated 
with $L$. plantarum remained in good quality for up to 6 months of storage based on the recommendation by Department of Agriculture and Rural Development, Government of Alberta [14]. On the other hand, after 6 months of storage, the quality of naturally fermented silage was less stable and remained only in moderate quality of silage. This result indicates that using L. plantarum inoculants for ensilaging can contribute to better quality of silage with extended storage time.

\section{Chemical composition of silage}

Almost all of nutrient compositions measured did not differ significantly when compared inoculated silage with control fermentation. However, significantly greater dry matter and organic matter content of silage in control group were observed (Table 2). The reduction in DM concentration was greater in LAB compared to that of control group, which may due to the inclusion of LAB that increased water production because of greater fermentation activity, resulting in an increase of metabolic water, then the lower DM content in the inoculated silage was observed [19].

\section{Rumen degradability}

The result from this experiment are in consistent with previous studies, several L. plantarum strains have been shown to increase rumen in vitro fermentation [6] and lead to faster degradation rates in the rumen [20]. The faster degradation of roughage in rumen would be advantageous to the animal by increasing the rate of rumen passage, leading to increased feed intake and consequently increase animal production. Table 3 showed that inoculated silage was degraded faster during the first 24 hours. The first $24 \mathrm{~h}$ of silage degradation is critical, since rumen fluid is retained for about $27 \mathrm{~h}$ [21]. We infer from the data that the rate of rumen passage is greater when animal received inoculated silage, which could affect feed intake and growth performance (Animal performance section)

\section{Animal performance}

Animals received inoculated silage showed greater voluntary feed intake and average daily gain. It is interesting to note that voluntary feed intake of the animals receiving inoculated silage was higher than that of the control group by only $5.21 \%$ whereas average daily gain showed huge improvement of $42.29 \%$ (Table 5). These findings are consistent with previous studies. Winters at al. (2001) [22] reported that Charolais beef steers received inoculated Italian ryegrass silage ad libitum without concentrate supplementation showed significantly greater dry matter fed intake and live weight gain. Muck and Kung (1997) [23] reviewed several studies showing that

L. plantarum inoculated silage led to an increase dry matter intake and live weight gain in both growing beef steers and finishing beef steers. $L$. plantarum inoculated silage has a higher lactic acid content, which can be converted to propionate in the rumen and utilized as an energy source for growth in beef cattle [24]. Moreover, feeding ovine with LAB inoculated grass silage increase total bacterial production in the rumen $[6,25]$ and improved nitrogen retention [26, 27]. In addition, The LAB used for silage inoculants may survive in the rumen which, can be beneficial for the fermentation process in the rumen [28] by inhibiting the growth of undesirable bacteria [29] resulting in improving efficiencies of rumen fermentation. Chen et al. (1992) [30] also reported that 
high dry matter intake increased microbial synthesis in the rumen and also bacteria/ $\mathrm{N}$ flow to the small intestine.

\section{Conclusion}

This study showed that Napier Pakchong 1 grass silage fermented with L. plantarum BCC65951 has a better fermentative quality in all parameters measured namely lower $\mathrm{pH}$ value, higher lactic acid and lower acetic acid concentration when compare with control fermentation. In addition, the ensiling Napier grass silage with L. plantarum BCC6595 improved voluntary feed intake and growth performance of Brahma cattle. L. plantarum BCC65951 is suggested as a starter culture organism for making good quality silage in the tropical zone from forage with low dry matter content and/or low epiphytic lactic acid bacteria.

\section{Abbreviations}

DM: Dry matter; CP: Crude protein; EE: Ether extract; CF: Crude fiber; NDF: Neutral detergent fiber; ADF: Acid detergent fiber; ADL: Acid detergent lignin; MBY: Microbial biomass yield; VFAs: Volatile fatty acids; GC: Gas chromatography; HPLC-UV: High-Performance Liquid Chromatography-Ultraviolet

\section{Declarations}

\section{Acknowledgements}

The authors would like to convey our deep gratitude to the staffs of Beef Cattle Research and Development Center, Bureau of Animal Husbandry and Genetic Improvement, for supporting us throughout the animal study period. We thank Phillip Shaw and Samaporn Teeravechyan for suggestions and input on the manuscript.

\section{Authors' contributions}

SS, SY and VP conceived and designed the experiments. SK and KT, performed animal experiments, analyzed the data and wrote the manuscript. KK and IP assisted with data analysis and paper writing. All authors read and approved the final manuscript.

\section{Funding}

This work was supported by the National Science and Technology Development Agency, Thailand

\section{Availability of data and materials}

All data generated or analyzed during this study are included in this article.

\section{Ethics approval}


The Institutional Animal Care and Use Committee, National Center for Genetic Engineering and Biotechnology, Thailand, has approved this research project in accordance with the Ethical Principles for the Use of Animals for Scientific Purposes issued by the National Research Council of Thailand. The approval for the Care and Use of Animals for Scientific Purposes Code BT-Animal 15/2559 was grant on September 2016.

\section{Consent for publication}

Not applicable.

\section{Competing interests}

The authors declare that they have no competing interests.

\section{References}

1. Kiyothong K. A super grass from Thailand. http://www.zacsarian.com/a-super-grass-from-thailand/. Accessed 30 Nov 2017.

2. Cai Y, Ohmomo S, Kumai S. Distribution and lactate fermentation characteristics of lactic acid bacteria on forage crops and grasses.1994. 420-8 p.

3. Pholsen S, Khota W, Pang H, Higgs D, Cai Y. Characterization and application of lactic acid bacteria for tropical silage preparation. Anim Sci J. 2016;87(10):1202-11.

4. Driehuis F, Oude Elferink SJWH, Van Wikselaar PG. Fermentation characteristics and aerobic stability of grass silage inoculated with Lactobacillus buchneri, with or without homofermentative lactic acid bacteria. Grass \& Forage Science. 2001;56(4):330-43.

5. Bureenok S, Yuangklang C, Vasupen K, Schonewille JT, Kawamoto Y. The effects of additives in napier grass silages on chemical composition, feed intake, nutrient digestibility and rumen fermentation. Asian-Australasian journal of animal sciences. 2012;25(9):1248-54.

6. Contreras-Govea FE, Muck RE, Broderick GA, Weimer PJ. Lactobacillus plantarum effects on silage fermentation and in vitro microbial yield. Animal Feed Science and Technology. 2013;179(1):61-8.

7. Canale A, E. Valente M, Ciotti A. Determination of volatile carboxylic acids (C1-C5i) and lactic acid in aqueous acid extracts of silage by High Performance Liquid Chromatography. 1984. 1178-82 p.

8. De Baere S, Eeckhaut V, Steppe M, De Maesschalck C, De Backer P, Van Immerseel F, et al.

Development of a HPLC-UV method for the quantitative determination of four short-chain fatty acids and lactic acid produced by intestinal bacteria during in vitro fermentation. J Pharm Biomed Anal. 2013;80:107-15.

9. AOAC. Official Methods of Analysis. 17th ed. Association of Official Analytical Chemists, 2005; Maryland, USA.

10. Van Soest PJ, Robertson JB, Lewis BA. Methods for dietary fiber, neutral detergent fiber, and nonstarch polysaccharides in relation to animal nutrition. J Dairy Sci. 1991;74(10):3583-97. 
11. Blümme/M, Ørskov E R. Comparison of gas production and nylon bag degradability of roughages in predicting feed intake in cattle. J Anim Feed Sci. 1993. 40, 109-119.

12. Blümmel M, Makkar H P S, Becker K. In vitro gas production: a technique revisited. J Anim Physiol An N. 1997. 77, 24-34.

13. Steel R G D, Torrie J H. Principles and Procedures of Statistics. 2nd ed. 1980. New McGraw-Hill.

14. Aasen A, Baron V S, Clayton G W, Dick A C, McCartney D H. Swath grazing potential of spring cereals, field pea and mixtures with other species. Can J Plant Sci. 2004. 84, 1051-1058.

15. Amanullah SM, Kim DH, Lee HJ, Joo YH, Kim SB, Kim SC. Effects of microbial additives on chemical composition and fermentation characteristics of barley silage. Asian Austral J Anim. 2014;27(4):5117.

16. Cao Y, Cai Y, Takahashi T, Yoshida N, Tohno M, Uegaki R, et al. Effect of lactic acid bacteria inoculant and beet pulp addition on fermentation characteristics and in vitro ruminal digestion of vegetable residue silage. J Dairy Sci. 2011;94(8):3902-12.

17. Li J, Shen Y, Cai Y. Improvement of Fermentation Quality of Rice Straw Silage by Application of a Bacterial Inoculant and Glucose. Asian-Australas J Anim Sci. 2010;23(7):901-6.

18. Tohno M, Kobayashi H, Nomura M, Kitahara M, Ohkuma M, Uegaki R, et al. Genotypic and phenotypic characterization of lactic acid bacteria isolated from Italian ryegrass silage. Anim Sci J. 2012;83(2):111-20.

19. McDonald P, Henderson A R, Heron S J E. The Biochemistry of silage. 2nd ed. Aberystwyth, UK:Chalombe Publications; 1991.

20. Harikrishna C, Mahender M, Reddy Y, Prakash M, Sudhakar K, Pavani M. Evaluation of in vitro gas production and nutrient digestibility of complete diets supplemented with different levels of thermotolerant yeast in Nellore rams. Veterinary World. 2012;5(8):477.

21. Hartnell G, D. Satter L. Determination of Rumen Fill, Retention Time and Ruminal Turnover Rates of Ingesta at Different Stages of Lactation in Dairy Cows. 1979. 381-92 p.

22. Winters AL, Fychan R, Jones R. Effect of formic acid and a bacterial inoculant on the amino acid composition of grass silage and on animal performance. Grass and Forage Science. 2001;56(2):18192.

23. Muck R E, Kung L. Effects of silage additives on ensiling. Proceedings of the silage: Field to Feed Bunk. North American Conference, Hershey, Pennsylvania. 11-13 Feb. 1997.

24. Charmley E. Towards improved silage quality - A review. Canadian Journal of Animal Science. 2001;81(2):157-68.

25. Contreras-Govea FE, Muck RE, Mertens DR, Weimer PJ. Microbial inoculant effects on silage and in vitro ruminal fermentation, and microbial biomass estimation for alfalfa, bmr corn, and corn silages. Anim Feed Sci Tech. 2011;163(1):2-10. 
26. Nkosi BD, Meeske R, van der Merwe HJ, Groenewald IB. Effects of homofermentative and heterofermentative bacterial silage inoculants on potato hash silage fermentation and digestibility in rams. Anim Feed Sci Tech. 2010;157(3):195-200.

27. Nkosi BD, Meeske R, Langa T, Thomas RS. Effects of bacterial silage inoculants on whole-crop maize silage fermentation and silage digestibility in rams. S Aft J Anim Sci. 2011;41:350-9.

28. Weinberg ZG, Muck RE, Weimer PJ. The survival of silage inoculant lactic acid bacteria in rumen fluid. J Appl Microbiol. 2003;94(6):1066-71.

29. Gollop N, Zakin V, Weinberg ZG. Antibacterial activity of lactic acid bacteria included in inoculants for silage and in silages treated with these inoculants. J Appl Microbiol. 2005;98(3):662-6.

30. Chen XB, Chen YK, Franklin MF, Orskov ER, Shand WJ. The effect of feed intake and body weight on purine derivative excretion and microbial protein supply in sheep. J Anim Sci. 1992;70(5):1534-1542.

\section{Figures}

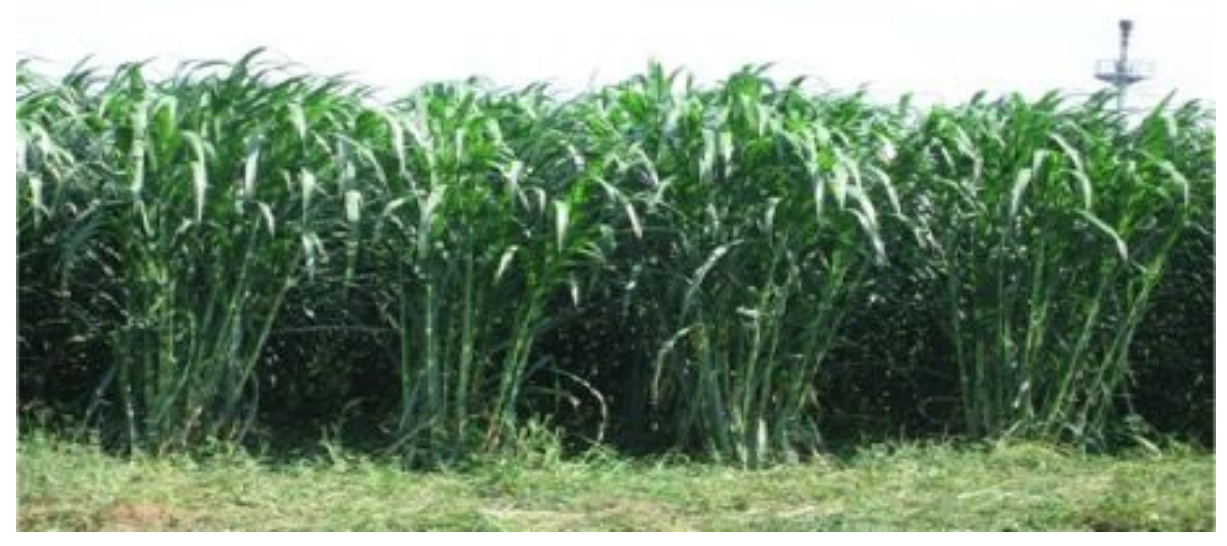

\section{Figure 1}

Napier Pakchong 1 at 45 days of mutualit 